Autor:

Augusto do Amaral Dergint

Título:

\title{
Responsabilidade do estado por atos judiciais
}

Banca Examinadora:

Presidente: Dr. Clemerson Merlin Cleve

Dr. Manoel de Oliveira Franco Sobrinho

Dra. Maria Sylvia Zanella di Pietro (USP)

Defesa: $\quad 11$ de novembro de 1993.

\section{Resumo}

Após analisar a evolução da responsabilidade estatal e as teorias lhe pertinentes, faze-se visita ao direito comparado para conhecer as soluções por ele encontradas para o problema da atividade judiciária danosa. Dentro da atividade do Poder Judiciário, distingue-se entre atos jurisdicionais e atos administrativos, para considerar a responsabilidade estatal atinente a estes. Caracteriza-se, em seguida, o serviço público, examina-se, então a teoria da irresponsabilidade do Estado por atos judiciais, criticando seus principais possíveis fundamentos: soberania do Poder Judiciário, incontrastabilidade da coisa julgada, falibilidade contingencial dos juízes, risco do erro judiciário assumido pelos jurisdicionados, independência da magistratura e ausência de texto legal expresso (prevendo a responsabilidade). Depois de apontar o artigo 37, parágrafo 6., da Constituição Federal de 1988 como fundamento da responsabilidade estatal, por atos judiciais (aplicáveis tanto a teoria do risco quanto a da falta do serviço), investigam-se hipóteses em que esta pode ser engendrada: erro judiciário (Penal e Civil), denegação de Justiça, demora na prestação da tutela jurisdicional, dolo e culpa do juiz. Por derradeiro, revela-se a situação da matéria na jurisprudência a pátria. 